\title{
Comparison of minimally invasive preperitoneal (MIP) single-layer mesh repair and total extraperitoneal (TEP) repair for inguinal hernia in terms of postoperative chronic pain: a prospective randomized trial
}

\author{
Nergis Aksoy ${ }^{1}$, Kemal Arslan ${ }^{1}$, Osman Doğru ${ }^{1}$, Ömer Karahan², Mehmet Ali Eryılmaz ${ }^{1}$ \\ ${ }^{1}$ Clinic of General Surgery, Konya Education and Research Hospital, Konya, Turkey \\ ${ }^{2}$ Department of General Surgery, Usak University School of Medicine, Usak, Turkey
}

\begin{abstract}
Objective: The aim of this study was to compare minimally invasive preperitoneal (MIP) single layer mesh repair with total extraperitoneal (TEP) inguinal hernia repair in terms of complications, recurrence, and chronic pain.

Material and Methods: A total of 240 patients who underwent elective, primary, unilateral inguinal hernia operation between April 2011 and September 2012 were divided into two randomized groups. The first group underwent MIP repair and the second group underwent TEP repair. Visual Analogue Scale (VAS) and Sheffield Scale (SS) were used to evaluate chronic pain.

Results: In all, 225 (95\%) of the patients completed follow-up and were included in analyses. A significant difference was not detected between groups in terms of demographics, operative time, or intraoperative, early, or late complications. Length of time before return to work was significantly shorter in the TEP group $(p<0.001)$. Recurrence was seen in $1(0.88 \%)$ patient in the MIP group and $1(0.89 \%)$ patient in the TEP group ( $p=0.993)$. Evaluation of chronic pain revealed no significant difference between groups in VAS and SS values at postoperative $6^{\text {th }}, 12^{\text {th }}$, and $24^{\text {th }}$ months.

Conclusion: In conclusion, it was observed that MIP repair for inguinal hernia has all of the advantages of preperitoneal repair and eliminates disadvantages of TEP repair. MIP technique is as safe as TEP repair and has similar qualities in terms of chronic pain, even though it is an open intervention.

Keywords: Chronic pain, inguinal hernia, preperitoneal repair, total extra peritoneal repair
\end{abstract}

Cite this article as: Aksoy N, Arslan K, Doğru O, Karahan Ö, Eryılmaz MA. Comparison of minimally invasive preperitoneal (MIP) single-layer mesh repair and total extraperitoneal (TEP) repair for inguinal hernia in terms of postoperative chronic pain. Turk J Surg 2019; 35 (1): 35-43

\section{Corresponding Author}

Nergis Aksoy

E-mail: drnergisaksoy@hotmail.com

Received: 26.04 .2018

Accepted: 21.06 .2018

Available Online Date: 01.03.2019

(C) Copyright 2019 by Turkish Surgical Society Available online at www.turkjsurg.com

DOI: $10.5578 /$ turkjsurg.4128

\section{INTRODUCTION}

High recurrence rates have been observed in classic hernia repairs due to the tension created when tissue is pulled together to close myopectineal orifice. Newer tension-free techniques have led to greatly diminished recurrence rates. This is an advantage; however, pain and fibrosis that can develop due to the mesh used are important subjects of discussion (1).

Although most related studies have examined Lichtenstein and laparoscopic repairs, it may be a mistake to make direct comparison of the two techniques. In the Lichtenstein repair, mesh is placed on premuscular layer, not preperitoneal surface, as in laparoscopic techniques. Therefore, it may be more useful to compare open and laparoscopic techniques that are similar in terms of dissection site, use of preperitoneal plane for mesh placement, and surfaces covered by the mesh. Review of the literature yielded no prospective randomized trials comparing chronic pain and long-term results of TEP and Kugel methods of repair.

The aim of this study was to prospectively examine minimally invasive preperitoneal (MIP) single-layer mesh repair with total extraperitoneal (TEP) repair in terms of operative time, length of time before return to work, early and late period complications, recurrence, and chronic pain.

\section{MATERIAL and METHODS}

This prospective, randomized study was conducted at the General Surgery Clinic of Konya Education and Research Hospital after having received approval of the ethics committee of Uşak University Medical School. Patients who presented to general 
surgery polyclinics of the hospital and who were scheduled to undergo surgery for inguinal hernia between April 2011 and September 2012 were assessed. Patients who met the study criteria were informed about the goals and content of the study preoperatively, and written consent was obtained from participants.

Patients over the age of 18 who were to undergo elective, unilateral inguinal hernia repair were included in the study. Recurrent cases that had already undergone hernia repair to the same side, patients with systemic disease (American Society of Anesthesiology Classification IV patients) that led to general disorders, and those who had undergone laparotomy for prostate, bladder, or in iliac region were excluded.

Patients who met the study criteria were enrolled beginning in April 2011 and inclusion was terminated in September 2012. Study was conducted with a total of 240 patients randomly divided into two groups of 120 using a computer program. One group underwent MIP repair and the other had TEP repair. Follow-up period was determined to be a minimum of 24 months. Study was concluded in September 2014. Information related to the patients who could not be followed up for any reason was not included in the analyses. Calculations were made using the data of the patients who completed follow-up and whose files did not have any missing information or otherwise, the participant was excluded.

Primary endpoints this study assessed were peroperative groin pain and postoperative $6^{\text {th }}, 12^{\text {th }}$, and $24^{\text {th }}$ months with VAS and SS. Secondary endpoints were operation time, length of hospital stay, time of return to work, complications, and recurrence.

The questionnaires were made until the 24th month: however, the patients were followed up until 36 months for recurrence.

Two hundred and twenty patients were included into to this study. This sample size was adequate to determine inter-ratio reliabilities described by Gheorghe D and Robert L. Considering that $10 \%$ of the patients would be lost during follow-up, 240 patients were included into the study (2).

\section{Surgical Method}

All procedures were performed by two experienced surgeons or under their supervision. General anesthesia was given to all patients in the TEP group. Predominantly, spinal anesthesia was used for the MIP group, and general anesthesia was used when necessary. Local anesthesia was not administered to any patients. All patients were intravenously administered $1 \mathrm{~g}$ cefazolin sodium as prophylactic.

\section{Minimally Invasive Preperitoneal (MIP) Single-Layer Mesh Repair}

This technique can be defined as a modification of Kugel repair. Surgical technique is similar; however, the mesh used has different qualities. Two-layer mesh with extreme polypropylene load

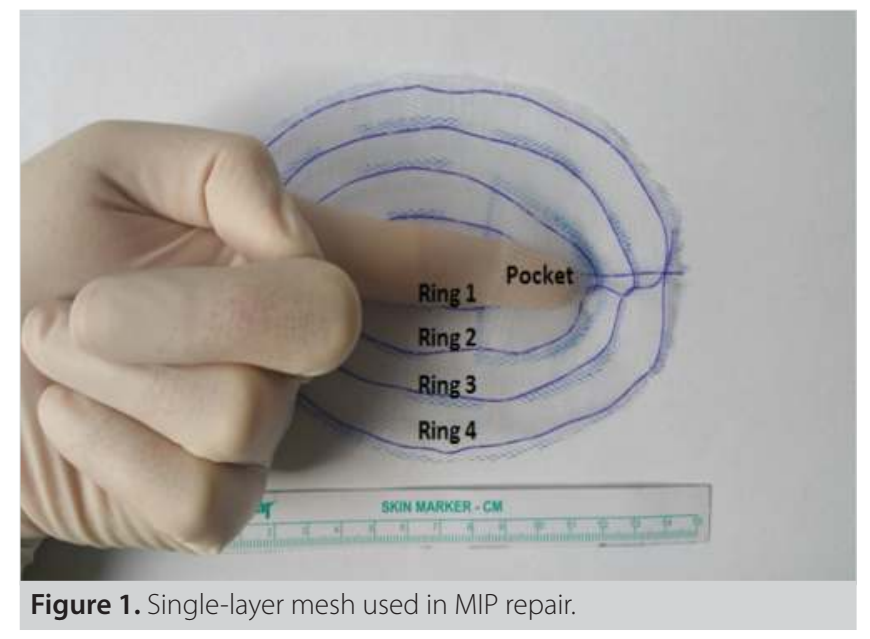

is used in Kugel hernia repair, which leads to greater cost and increased foreign object reaction (Kugel's Patch; Surgical Sense, Inc., Arlington, TX, USA).

Monofilament $38 \mathrm{~g} / \mathrm{m}^{2}$ polypropylene mesh, $15 \times 15 \mathrm{~cm}$ in size, was used in MIP repair (Supromesh; Sayın Tıp Ticaret, İstanbul, Turkey). The mesh was cut to oval shape, $14 \times 9 \mathrm{~cm}$ in size, and 4 memory recoil rings were added to the prepared mesh with absorbable monofilament synthetic polydioxanone suture (Pedesente, Doğsan Surgical Sutures, Ankara, Turkey). In size $2 \times 2$ $\mathrm{cm}$ pocket added on the prepared mesh with the same material. This pocket was created for the surgeon's index finger during blind placement of the mesh in the preperitoneal space. Polypropylene load is reduced in comparison to the original mesh of Kugel repair. Specially prepared mesh was then sterilized with hydrogen peroxide and packaged for use in MIP repair (Figure 1).

\section{Surgical Technique}

A 3-cm skin incision was made two-thirds medial and one-third lateral to the line connecting pubic tubercle with spina iliaca anterior superior. After passing through subcutaneous tissue and Camper's and Scarpa's fasciae, aponeurosis of abdominal external oblique muscle was opened parallel to fibers while protecting nerves.

Transverse fascia was reached by opening in the direction of abdominal internal oblique and transverse muscle fibers. Transverse fascia was opened perpendicularly to the abdominal incision so as not to injure inferior epigastric artery and vein, and preperitoneal space was entered.

In case of indirect hernia, hernia sac can usually be easily separated from the spermatic cord. When that is not possible, the sac is cut at the level of distal deep inguinal ring, left inside the inguinal canal, and closed proximally.

Dissection was continued until there was 3 to $4 \mathrm{~cm}$ between the peritoneum and the cord and its elements. After completing the dissection of the hernia sac, a pocket was made in the 
preperitoneal space for mesh placement with blunt dissection. Pocket reached to pubic symphysis medially, $3 \mathrm{~cm}$ lateral to deep inguinal ring, and $3 \mathrm{~cm}$ under inguinal ligament and over conjoint tendon. The mesh was placed blindly in the preperitoneal space. Then with thw help of a retractor, three-fifths of the mesh was over the inguinal ligament and two-fifths was underneath. If spinal anesthesia was used, the patient was asked to cough to check the positioning of the mesh and whether there was any herniation. If necessary, the mesh was re-positioned. In patients under general anesthesia, positioning was confirmed once the patient awoke from anesthesia. The mesh cannot be fixed anywhere after it has been placed; however, the suture is attached by passing from the mesh when transverse fascia is closed. Following layers are closed in their anatomical order.

\section{Laparoscopic Total Extraperitoneal (TEP) Repair}

The procedure was performed under general anesthesia. The patient was put in supine and 15-degree Trendelenburg position. The surgeon stood on side opposite to the site where hernia repair would take place, and camera assistant and nurse stood opposite the surgeon. Patients had preoperatively emptied bladder and no urinary catheters were used.

One 10-mm and two 5-mm trocars were used in all patients. Following the incision under umbilicus toward the herniated site, 10-mm trocar was inserted. Two 5-mm trocars were placed over the midline, one $2 \mathrm{~cm}$ over the pubic symphysis and the other between the umbilicus and the first trocar. Anterior rectus sheath was reached with $2 \mathrm{~cm}$ incision to the sub-umbilical region. Sheath was opened with transverse incision to reach the rectus muscle and posterior rectus sheath. Following blunt dissection, preperitoneal space was enlarged by entering the space formed with 10-mm trocar. At this stage, carbon dioxide was added at pressure of $10 \mathrm{mmHg}$. Pubic symphysis was reached with angled laparoscope $\left(30^{\circ}\right)$. Dissector with curved tip and flat grasper were generally used for dissection. Dissection continued toward the rectus muscle until reaching the location where sub-umbilical was above, midline medial, Retzius space below, Bogros region inferolateral, and anterior superior iliac spine. Guide points such as pubic symphysis, Cooper's ligament, pubis, inferior epigastric vessels, spermatic cord and its elements, myopectineal openings, and fascia of the psoas muscle were fixed. Hernia sac was revealed and all adhesions were removed as far as the peritoneum. Sac and testicular veins were separated from the posterior margin of vas deferens. Hernia sac was separated from the cord structure. The openings formed in the peritoneum during dissection were sutured. In case of large direct hernia, widened transverse fascia was fixed to Cooper's ligament by rotating it inwardly. Non-absorbable monofilament polypropylene mesh, approximately $16 \times 12 \mathrm{~cm}$ in size according to patient anatomy, was prepared and inserted to the field in a roll. The mesh was uniformly spread out after placement such that it reached at least $2 \mathrm{~cm}$ under Cooper's ligament and passed through midline, covering the pubis bone after stapling to Cooper's ligament. Non-absorbable titanium tack (ProTack $5 \mathrm{~mm}$ fixation device, Covidien, Dublin, Ireland) was used for fixation in TEP repair. Five tackers were used (3 on pubis and Cooper's ligament and remainder on medial part of inferior epigastric vessels, transverse fascia, and superior lateral side with bimanual technique) in the fixation procedure to avoid use of stapler on the lateral side of the external iliac artery and vein or the inferior side of the lateral of the ileopubic tract. Gas was released slowly under direct vision. Fascia at location of 10-mm trocar was approximated with absorbable suture material, and skin incision was approximated with non-absorbable suture material.

Physical examination determined the type of hernia and was confirmed by findings during operation.

\section{Evaluation of Patient Characteristics and Chronic Pain}

Demographic information (age, gender, body mass index [BMI]) of the patients, hernia type according to Gilbert classification as modified by Rutkow and Robbins, operative time from first skin incision to closure, perioperative and postoperative early complications, and length of hospital stay were recorded in files prepared specifically for this study.

Postoperatively, all patients were called for a follow-up visit at the end of 1 week. Patients were then called for routine visits in postoperative $1^{\text {st }}, 6^{\text {th }}, 12^{\text {th }}$ and $24^{\text {th }}$ months. Annual follow-up was recommended after postoperative first year. Necessary work-up was requested for patients in whom pathological findings or suspected findings were detected during follow-up visits, and those patients were called for follow-up visits at more frequent intervals for appropriate treatment. Postoperative complications and length of time to return to work or return to physical activity for those who were not working were recorded.

A questionnaire was administered to all patients preoperatively and at $6^{\text {th }}, 12^{\text {th }}$, and $24^{\text {th }}$ postoperative months to evaluate pain. Patients who could not come to long term follow-up visits were reached by phone and questioned regarding hernia repair. Visual Analogue Scale (VAS) was used simultaneously with the Sheffield Scale (SS) to determine pain severity and make comparison.

\section{Visual Analogue Scale (VAS)}

The scale was composed of a horizontal line, $100 \mathrm{~mm}$ in length. The phrase "No pain" appeared at the left end of the line, and the phrase "Excruciating pain" appeared at the right end. Patient was asked to mark the spot on the line best describing their pain. Distance of the mark to the left end is measured in millimeters and reported as "score."

\section{Sheffield Scale (SS)}

Pain with regard to physical activity was also assessed with simple three-point scale. Patients were asked to rate their experience as follows: 0 : Patient feels no pain; 1: There is no pain during rest but 
pain manifests itself during movement; 2 : There is occasional pain during rest, but it is mild during movement; 3 : Pain is constantly present during rest and intensifies during movement. High values are associated with severity of chronic pain and low quality of life. As scale is simple to understand and does not require the patient to provide excessive detail or time to administer, it is considered a very useful assessment tool.

\section{Statistical Analysis}

All statistical analyses were performed by SPSS software, version 16.0 (SPSS, Inc., Chicago, IL, USA). Categorical data were presented as frequencies and percentages, and continuous variables were presented as mean \pm standard deviation in tables. Kolmogorov-Smirnov test was applied to determine if numerical values correlated with normal distribution. Mann-Whitney $U$ test was performed to compare two population means. Chi-square test was used to compare categorical variables across groups . p value of less than 0.05 was considered as statistically significant in all analyses.

\section{RESULTS}

Of the 269 patients who presented to the general surgery polyclinics and met the criteria of the study, 29 declined to participate and were excluded. A total of 240 patients who accepted the conditions of the study were randomly divided into 2 groups: 120 in MIP group and 120 in TEP group.

In the MIP group, one (0.84\%) patient could not be reached for postoperative first month follow-up, 2 (1.7\%) patients for 6th month follow-up, $1(0.84 \%)$ patient for $12^{\text {th }}$ month, and $3(2.5 \%)$ patients for $24^{\text {th }}$ month follow-ups. These 7 (5.8\%) patients were excluded from the study and data were not included into the analyses. Follow-up rate in the MIP group was 94.2\% (Figure 2).

Pneumoperitoneum developed in one patient in the TEP group after perioperative peritoneum damage necessitating Lichtenstein repair. In addition, TEP repair could not be performed on one (0.84\%) patient due to surgeon-related and/or technical reasons. One additional patient (0.84\%) was excluded upon detecting urolithiasis during follow-up in order not to influence pain scores. Those two (1.7\%) patients were excluded from the study. In the TEP group, two (1.7\%) patients could not be reached for sixth month follow-up, and 4 (3.4\%) could not be reached for $12^{\text {th }}$ month follow-up; therefore, these $6(5 \%)$ patients were also excluded. Follow-up rate in the 120 patients included in the TEP group was $93.4 \%$. Analyses were conducted with the data of a total of 225 patients, 113 (50.2\%) in the MIP group, and 112 (49.8 \%) in the TEP group.

Majority of the patients had indirect inguinal hernias (Table 1).

General anesthesia was used for all patients in the TEP group $(n=112)$, and 14 patients (13.3\%) of the 113 included in the MIP group; the remainder of the MIP group patients received spinal anesthesia.

No statistically significant difference was detected in terms of age, gender, BMI, operative time, length of hospital stay, or mean follow-up period between the groups (Table 2).

Period before return to work/daily activities was significantly shorter in the TEP group $(p<0.001)$ (Table 2).

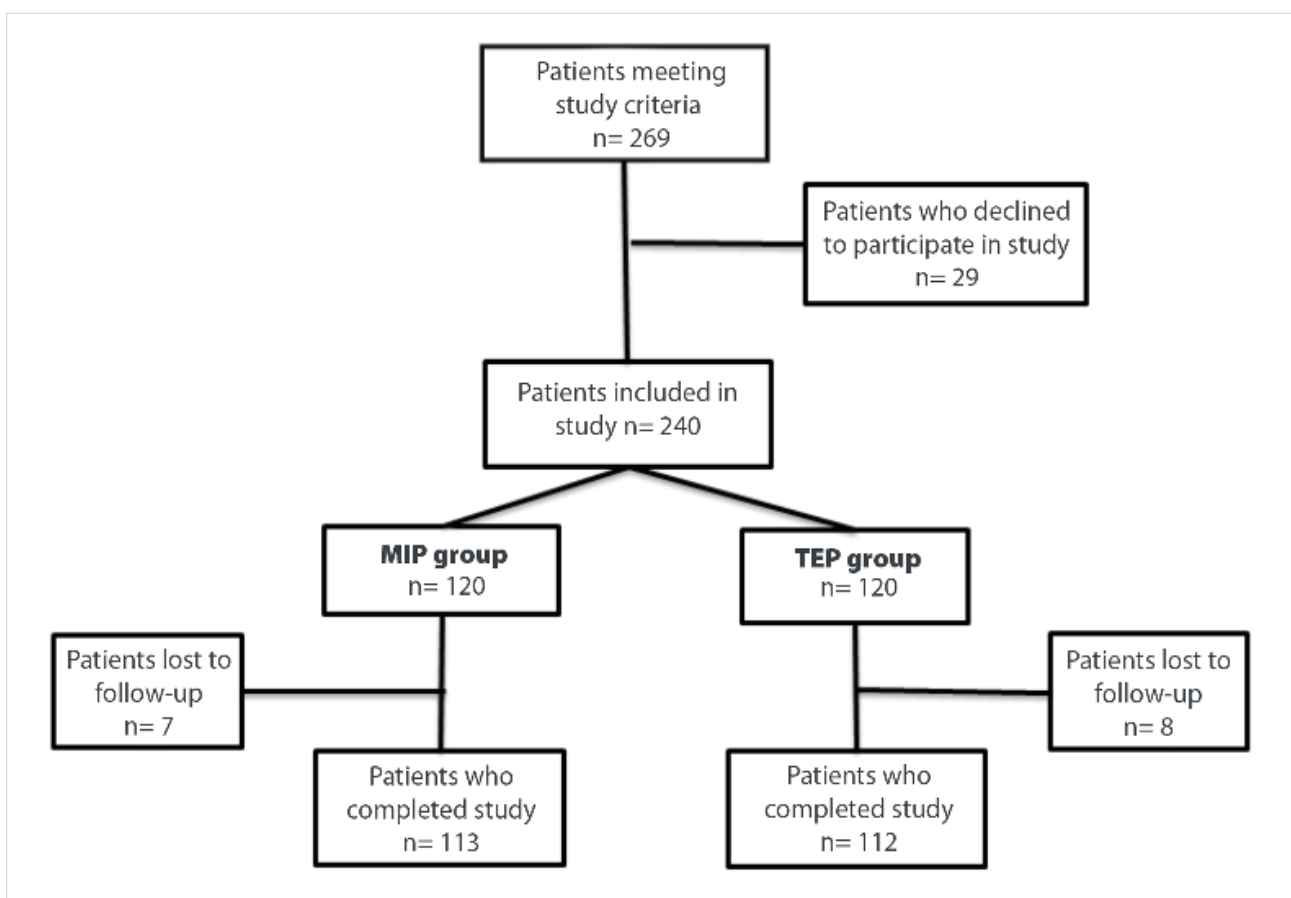

Figure 2. Patient follow-up chart. 


\begin{tabular}{|c|c|c|}
\hline & $\begin{array}{c}\text { MIP } \\
n=113\end{array}$ & $\begin{array}{c}\text { TEP } \\
\mathrm{n}=112\end{array}$ \\
\hline Type 1 Indirect hernia, intact inner ring & 18 & 16 \\
\hline Type 2 Indirect hernia, extended inner ring $\leq 4 \mathrm{~cm}$ & 52 & 49 \\
\hline Type 3 Indirect hernia, inner ring $>4 \mathrm{~cm}$ & 15 & 16 \\
\hline Type 4 Direct hernia, posterior wall of inguinal canal is defective & 18 & 20 \\
\hline Type 5 Direct hernia, diverticular defect in suprapubic position & 1 & 0 \\
\hline Type 6 Simultaneous direct and indirect component & 8 & 8 \\
\hline Type 7 Femoral hernia & 1 & 3 \\
\hline
\end{tabular}

Table 2. Demographic characteristics and follow-up

\begin{tabular}{|l|c|c|c|}
\hline & MIP & TEP \\
$\mathbf{n = 1 1 3}$ & $\mathbf{n}=\mathbf{1 1 2}$ & $\mathbf{p}$ \\
\hline Age & $44.89 \pm 13.692$ & $44.28 \pm 14.051$ & 0.738 \\
\hline Body mass index & $27.20 \pm 8.24$ & $25.92 \pm 3.58$ & 0.669 \\
\hline Operative time (minutes) & $41.73 \pm 16.06$ & $43.26 \pm 14.81$ & 0.132 \\
\hline Length of hospital stay (days) & $1.05 \pm 0.26$ & $1.04 \pm 0.28$ & 0.494 \\
\hline Period before return to work (days) & $8.66 \pm 1.55$ & $7.16 \pm 1.43$ & $<\mathbf{0 . 0 0 1}$ \\
\hline Follow-up (months) & 33.12 (24-36) & $33.43(24-36)$ & 0.639 \\
\hline Data expressed as mean value \pm SD. Value in bold indicates statistical significance. MIP: Minimally invasive preperitoneal; TEP: Total extraperitoneal.
\end{tabular}

Complications developed in a total of 16 patients (14.16\%) in the MIP group. As perioperative complication, inferior epigastric vessels of one patient (0.88\%) were damaged and ligation was performed to stop hemorrhage. No additional complications were observed during postoperative follow-up of the patient. Postoperative early complications included pseudo hernia in 2 $(1.76 \%)$ patients, seroma in 5 (4.42\%) patients, cord edema in 3 $(0.88 \%)$ patients, scrotal edema in $1(0.88 \%)$ patient, ecchymosis in $1(0.88 \%)$ patient, hematoma in $1(0.88 \%)$ patient, and wound-site infection in 1 (0.88\%) patient. At sixth month visit, results for both patients with pseudo hernia were normal. Four instances of seroma had resolved at the end of 1 month, and fifth seroma was aspirated with injector upon observation of swelling. Follow-up was normal after aspiration. Cord edema, scrotal edema, and ecchymosis findings regressed in the first month of follow-up. Though there was no perioperative hemostasis difficulty, hematoma developed postoperatively in one patient. It was medically treated without drainage, as was not large and no growth was detected. First month follow-up of the patient was normal. Oral anti-biotherapy was administered to one patient who developed wound-site infection on postoperative day 5. Skin findings were normal at the second week follow-up visit and no additional treatment was required. Recurrence was detected in one patient (0.88\%) in the MIP group. Lichtenstein repair was performed on the $20^{\text {th }}$ month of follow-up, and it was observed that recurrence was the result of migration of the mesh (Table 3).

Complications were observed in a total of 14 (12.50\%) patients in the TEP group. Early postoperative complications included pseudo hernia in 6 (5.35\%) patients. Swelling in five patients disappeared at third month follow-up; however, upon seeing that it persisted in one patient, ultrasonography was performed and the condition was monitored to make sure there was no recurrence. Pseudo hernia regressed at sixth month follow-up. Seroma developed in 5 (4.46\%) patients, but all regressed after 1 month. Hematoma that developed in 1 (0.89\%) patient was resorbed on the $45^{\text {th }}$ day without necessitating further intervention. Scrotal edema that developed in 1 (0.89\%) patient was seen to have regressed at first month follow-up visit.

Recurrence was detected in the $12^{\text {th }}$ month in 1 (0.9\%) patient in the TEP group, and Lichtenstein procedure was performed.

No significant difference between the groups was observed in terms of postoperative early complications or recurrence (Table 3).

Chronic pain was assessed preoperatively and postoperatively at 6, 12 and 24 months using visual analogue scale (VAS) and Sheffield pain scale (SS). Preoperative assessment of the patients revealed that 64 (28.4\%) patients had no pain, 66 (29.3\%) patients reported pain in activities but no pain at rest, 71 (31.5\%) 
Table 3. Complications and recurrence

\begin{tabular}{|c|c|c|c|}
\hline & $\begin{array}{c}\text { MIP } \\
n=113 n(\%)\end{array}$ & $\begin{array}{c}\text { TEP } \\
n=112 n(\%)\end{array}$ & p \\
\hline Recurrence & $1(0.88)$ & $1(0.89)$ & 0.993 \\
\hline Pseudo hernia & $2(1.76)$ & $6(5.35)$ & 0.147 \\
\hline Seroma & $5(4.42)$ & $5(4.46)$ & 0.989 \\
\hline Cord edema & $3(2.65)$ & 0 & 0.083 \\
\hline Scrotal edema & $1(0.88)$ & $1(0.89)$ & 1.000 \\
\hline Ecchymosis & $1(0.88)$ & 0 & 0.322 \\
\hline Hematoma & $1(0.88)$ & $1(0.89)$ & 0.995 \\
\hline Wound-site infection & $1(0.88)$ & 0 & 0.319 \\
\hline Inferior epigastric vessel damage & $1(0.88)$ & 0 & 0.319 \\
\hline
\end{tabular}

Table 4. Distribution of preoperative Sheffield Scale scores

\begin{tabular}{|c|c|c|c|}
\hline & $\begin{array}{c}\text { MIP } \\
n=113\end{array}$ & $\begin{array}{c}\text { TEP } \\
\mathrm{n}=112\end{array}$ & Total n (\%) \\
\hline 0: No pain & 31 & 33 & $64(28 \%)$ \\
\hline 1: Pain present only during movement & 34 & 32 & $66(29 \%)$ \\
\hline 2: Occasional pain during rest, mediocre pain present during movement & 37 & 34 & $71(32 \%)$ \\
\hline 3: Pain present constantly during rest, severe pain during movement & 11 & 13 & $24(11 \%)$ \\
\hline
\end{tabular}

Table 5. Mean pain scores of the groups and $p$ value over time

\begin{tabular}{|c|c|c|c|c|}
\hline & & MIP Group & TEP Group & $p$ \\
\hline \multirow[t]{2}{*}{ Preoperative Period } & Visuale analoque scale (VAS) & $23.54 \pm 2.13$ & $23.21 \pm 2.14$ & 0.893 \\
\hline & Sheffield scale (SS) & $1.25 \pm 0.09$ & $1.24 \pm 0.11$ & 0.925 \\
\hline \multirow[t]{2}{*}{ Postoperative $6^{\text {th }}$ month } & Visuale analoque scale (VAS) & $3.1 \pm 0.76$ & $2.86 \pm 0.69$ & 0.927 \\
\hline & Sheffield scale (SS) & $0.19 \pm 0.04$ & $0.16 \pm 0.04$ & 0.954 \\
\hline \multirow[t]{2}{*}{ Postoperative $12^{\text {th }}$ month } & Visuale analoque scale (VAS) & $1.86 \pm 0.49$ & $1.52 \pm 0.41$ & 0.811 \\
\hline & Sheffield scale (SS) & $0.14 \pm 0.03$ & $0.13 \pm 0.03$ & 0.868 \\
\hline \multirow[t]{2}{*}{ Postoperative $24^{\text {th }}$ month } & Visuale analoque scale (VAS) & $1.59 \pm 0.43$ & $1.07 \pm 0.31$ & 0.513 \\
\hline & Sheffield scale (SS) & $0.13 \pm 0.03$ & $0.11 \pm 0.03$ & 0.556 \\
\hline
\end{tabular}

patients reported temporary pain at rest but constant pain during activities, and 24 (10.7\%) patients reported pain during activities and at rest (Table 4).

Mean preoperative VAS value was $23.54 \pm 21.34$ in the MIP group and $23.21 \pm 21.40$ in the TEP group. A significant difference was not detected between the groups ( $p=0.893$ ). Mean preoperative total SS score was 1.247 in the MIP group and 1.241 in the TEP group. Also, a significant difference was not detected between the groups ( $p=0.925)$. Mean VAS and SS scores of both groups were similar in postoperative $6^{\text {th }}, 12^{\text {th }}$, and $24^{\text {th }}$ months in terms of chronic pain (Table 5). Mean VAS and SS scores of both groups were similar in postoperative $6^{\text {th }}, 12^{\text {th }}$, and $24^{\text {th }}$ months in terms of chronic pain (Table 5).

\section{DISCUSSION}

Inguinal hernia is a common condition affecting all age groups, and is typically treated by general surgeons. High incidence rate and resulting need for repair surgery equate to high economic cost and loss to work force $(3,4)$. Despite being performed so often, there is no agreed optimal method providing patient comfort and low recurrence rates (5). Problem of recurrence 
has been reduced to a minimum in tension-free hernia repairs where mesh is used; however, chronic pain that can develop due to mesh has become the primary issue. The most important factor in determining the success of hernia repair is now patient comfort.

As a result of the studies evaluating anterior and posterior placement of mesh in terms of patient comfort, the European Hernia Society recommended in its 2009 guideline regarding hernia repair in adult patients that posterior repair methods are Level 1 B (6). In posterior repair techniques, complications related to the spermatic cord are reduced since the inguinal canal is not dissected, and possibility of chronic inguinal pain is reduced since neural structures remain outside the surgical area (7). Posterior repairs can be performed laparoscopically or as open surgery. In the literature review we conducted, present study authors did not find a prospective randomized study evaluating the effect of repair types on chronic pain, though there are limited number of studies comparing Kugel and TEP repairs. Therefore, in this study, comparison was made of TEP, which has advantages of minimally invasive surgery, and MIP procedure, which is similar to Kugel hernia repair, since both are preperitoneal and posterior repair methods.

Even though laparoscopic inguinal hernia repair has good results as a posterior intervention in terms of patient comfort and recurrence, it has disadvantages such as long surgical learning curve, requirement of general anesthesia, long operative time, and need for special equipment and related high costs. Another repair method eliminating these disadvantages and simultaneously providing patient comfort would be preferable. In this study, an alternative was compared to the laparoscopic method, and results were presented in order to add clarity to the matter.

The mesh used in original Kugel surgery has two layers and excessive polypropylene load. In addition, it is expensive and increases the cost of the surgery. Tissue compatibility of this 2-layer mesh has not been as expected and serious life-threatening complications have developed due to the fact that the mesh eroded surrounding tissue (8). Therefore, the original Kugel mesh was not used in MIP procedure in this study; singlelayer polypropylene mesh modified by Arslan and colleagues was used (9). Thus, the difference between the two groups in terms of the mesh used was eliminated.

Both groups were similar with respect to demographics such as age, gender, and BMI. Patients were operated on by surgeons experienced in both techniques so as to avoid errors stemming from the learning curve. Even though operative time was longer in the laparoscopy group, the difference was not statistically significant. Length of hospital stay was also similar in both groups.
Complication incidence rate was $14.2 \%$ in the MIP group and $12.5 \%$ in the TEP group. In both groups, complications were minor and at a rate similar to that seen in the literature $(10,11)$.

Although high recurrence rate of $25 \%$ has been reported in laparoscopic hernia repair early on, this rate has been later reported as 1.9\% in an MRC study (12,13). Rate of recurrence for TEP and transabdominal preperitoneal techniques have been reported as $1 \%$ to $2 \%$ and $0 \%$ to $3 \%$, respectively (14). In some meta-analyses, recurrence rates for open surgery and laparoscopic repair have been reported as $1.2 \%$ and $2.7 \%$, respectively $(15,16)$. Kugel, in his own study, has reported a $0.62 \%$ recurrence rate (17). Transinguinal preperitoneal repair and laparoscopic repairs have been compared in a recent study and recurrence rates have been found as $1.19 \%$ and $0.51 \%$, respectively (11). In the present study, $0.88 \%$ recurrence was recorded in the MIP group and $0.89 \%$ recurrence was seen in the TEP group, consistent with the literature. There was no significant difference between the groups in terms of recurrence.

Preference to use mesh in hernia repair led to significant improvement in recurrence rates and chronic pain has now become the new focus point. In the literature, frequency of chronic pain has been reported as between $12.9 \%$ and $53.6 \%$; it is now a more serious and common complication than recurrence (1822).

Rate of chronic inguinal pain after inguinal hernia repair has been reported as 12\% for all hernia repairs, 18\% (range: 0\%$75.5 \%$ ) in cases treated with open surgery, and 6\% (range: 1\%$16 \%)$ in laparoscopically treated cases in a study conducted by Aasvang and Kehlet, and lower rate of chronic pain incidence in laparoscopic repairs has been found to be significant when compared to open repairs (23).

Similar to results in the literature, rate of chronic pain in our study was $14.66 \%$ in all patients, $15.9 \%$ in the MIP group and $13.39 \%$ in the TEP group in postoperative $6^{\text {th }}$ month; $13.27 \%$ and $11.60 \%$, respectively, in postoperative $12^{\text {th }}$ month; and $13.27 \%$ and $10.71 \%$, respectively, in postoperative $24^{\text {th }}$ month. Although frequency of chronic pain in the MIP group was higher than that of the TEP group, difference was not statistically significant.

Return to daily activities or to work is an important criterion in evaluating the success of surgical intervention and is usually associated with postoperative pain status of the patient. Various studies have indicated that laparoscopic hernia repair causes less pain in both early and late periods when compared to open surgeries $(24,25)$. Patients cannot meet the economic needs of their family and are in need of help until they can carry out daily activities on their own. Hence, the length of this recovery period has effects on economy and social life. In our study, the length of time before returning to work or daily activities was 
significantly shorter in the TEP group. Although both methods of treatment are minimally invasive, this advantage of the laparoscopic method, as in other surgical interventions, was significantly different in the early postoperative period.

\section{CONCLUSION}

It was observed that MIP repair for inguinal hernia has the advantages of preperitoneal repair and eliminates disadvantages of TEP repair. MIP technique is as safe as TEP repair and has similar qualities in terms of chronic pain even though it is an open intervention. The experience of the surgeon, considering the patient's co-morbidities; MIP procedure with a low rate of recurrence and chronic pain; is an alternative to TEP.

Ethics Committee Approval: This prospective, randomized study was conducted at the General Surgery Clinic of Konya Education and Research Hospital after having received approval of the ethics committee of Uşak University Medical School.

Informed Consent: Written informed consent was obtained from patients who participated in this study.

Peer-review: Externally peer-reviewed.

Author Contributions: Consept - N.A., K.A., O.D.; Design - N.A., K.A.; Supervision - Ö.K., M.A.E., N.A.; Resource - O.D., N.A.; Materials - N.A.; Data Collection and/or Processing - N.A.; Analysis and Interpretation - N.A., K.A.; Literature Search - O.D., Ö.K., M.A.E.; Writing Manuscript - N.A., K.A., O.D., Critical Reviews - O.D., K.A., N.A.

Conflict of Interest: The authors have no conflicts of interest to declare.

Financial Disclosure: The authors declared that this study has received no financial support.

\section{REFERENCES}

1. Condon RE. Groin pain after hernia repair. Ann Surg 2001; 233:1-8. [CrossRef]

2. Doros G, Lew R. Design based on intra-class correlation coefficients. Am J Biostat 2010; 1: 1-8. [CrossRef]

3. Scotland DJ, Jones DB. Hernias and Abdominal Wall Defects. Norton $J A$, editor. Essential Practice of Surgery, Chapter 25. Springer-Verlag New York, Inc; 2003. pp. 335-54.

4. Velez-Gil A, Wilson D, Pelaez RN. A simplified system or surgical operations: The economics of treating hernia. Surgery 1975; 77: 391-4.

5. Treadwell J, Tipton K, Oyesanmi O, Sun F, Schoelles, K. Surgical options for inguinal hernia: comparative effectiveness review. Agency for Healthcare Research and Quality (US), Rockville (MD). 2012.

6. Simons MP, Aufenacker T, Bay-Nielsen M, Bouillot JL, Campanelli G, Conze J, et al. European Hernia Society guidelines on the treatment of inguinal hernia in adult patients. Hernia 2009; 13: 343-403. [CrossRef]

7. Ceriani V, Faleschini E, Bignami P, Lodi T, Roncaglia O, Osio C, et al. Kugel hernia repair: open "mini-invasive" technique. Personal experience on 620 patients. Hernia 2005; 9: 344-7. [CrossRef]

8. Kunishige T, Takayama T, Matumoto S, Wakatsuki K, Enomoto K, Tanaka T, et al. A defect of the abdominal wall within testinal fistul as after the repair of incisional hernia using Composix Kugel Patch. Int $J$ Surg Case Rep 2013; 4: 793-7. [CrossRef]
9. Arslan K, Erenoglu B, Turan E, Koksal H, Dogru O. Minimally invasive preperitoneal single-layer mesh repair versus standard Lichtenstein hernia repair for inguinal hernia: a prospective randomized trial. Hernia 2015; 19: 373-81. [CrossRef]

10. Bansal VK, Misra MC, Babu D, Victor J, Kumar S, Sagar R, et al. A prospective, randomized comparison of long-term outcomes: chronic groin pain and quality of life following totally extraperitoneal (TEP) and transabdominal preperitoneal (TAPP) laparoscopic inguinal hernia repair. Surg Endosc 2013; 27: 2373-82. [CrossRef]

11. Li J, Wang X, Feng X, Gu Y, Tang R. Comparison of open and laparoscopic preperitoneal repair of groin hernia. Surg Endosc 2013; 27(12): 4702-10. [CrossRef]

12. Neumayer L, Giobbie-Hurder A, Jonasson O, Fitzgibbons R Jr, Dunlop $D$, Gibbs J, et al Open mesh versus laparoscopic mesh repair of inguinal hernia. N Engl J Med 2004; 350: 1819-27. [CrossRef]

13. Laparoscopic versus open repair of groin hernia: a randomized comparison. The MRC Laparoscopic Groin Hernia Trial Group. Lancet 1999; 354: 185-90. [CrossRef]

14. Wake BL, McCormack K, Fraser C, Vale L, Perez J, Grant AM. Transabdominal preperitoneal (TAPP) vs totally extraperitoneal (TEP) laparoscopic techniques for inguinal hernia repair. Cochrane Database Syst Rev 2005; 1: CD004703. [CrossRef]

15. Grant AM. Laparoscopic versus open groin hernia repair: meta-analysis of randomized trials based on individual patients data. Hernia 2002; 6: 2-10. [CrossRef]

16. Grant AM. Open mesh versus non-mesh repair of groin hernia metaanalysis of randomized trials based on individual patient data. Hernia 2002; 6: 130-6. [CrossRef]

17. Kugel RD. Minimally invasive, non-laparoscopic, preperitoneal, and sutureless, inguinal herniorrhaphy. Am J Surg 1999; 178: 298-302. [CrossRef]

18. Franneby U, Sandblom G, Nordin P, Nyrén O, Gunnarsson U. Risk factors for long-term pain after hernia surgery. Ann Surg 2006; 244: 212-9. [CrossRef]

19. Callesen T, Bech K, Kehlet H. Prospective study of chronic pain after groin hernia repair. Br J Surg 1999; 86: 1528-31. [CrossRef]

20. Kumar S, Wilson RG, Nixon SJ, Macintyre MC. Chronic pain after laparoscopic and open mesh repair of groin hernia. Br J Surg 2002; 89: 1476-9. [CrossRef]

21. Lau H. Day-case endoscopic totally extraperitoneal inguinal hernioplasty versus open Lichtenstein hernioplasty for unilateral primary inguinal hernia in males: a randomized trial. Surg Endosc 2006; 20: 76-81. [CrossRef]

22. Sanjay $P$, Harris $D$, Jones $P$, Woodward A. Randomized controlled trial comparing Prolene hernia system and Lichtenstein method for inguinal hernia repair. ANZ J Surg 2006; 76: 548-52. [CrossRef]

23. Aasvang E, Kehlat H. Chronic postoperative pain: the case of inguinal herniorrhaphy. Br J Anaesth 2005; 95: 69-76. [CrossRef]

24. Collaboration EH. Laparoscopic compared with open methods of groin hernia repair: systematic review of randomized controlled trials. Br J Surg 2000; 87: 860-7. [CrossRef]

25. Gong K, Zhang N, Lu Y, Zhu B, Zhang Z, Du D, et al. Comparison of the open tension-free mesh-plug, transabdominal preperitoneal (TAPP), and totally extraperitoneal (TEP) laparoscopic techniques for primary unilateral inguinal hernia repair: a prospective randomized controlled trial. Surg Endosc 2011;25:234-9. [CrossRef] 


\title{
ORIJINAL ÇALIŞMA-ÖZET
}

Turk J Surg 2019; 35 (1): 35-43

\section{Kasık fıtıklarında tek yama ile minimal invaziv preperitonial (MiP) onarım ve total ekstra peritonial onarım (TEP) metodlarının postoperatif kronik ağrı yönünden karşılaştırılması; prospektif randomize çalışma}

\author{
Nergis Aksoy¹, Kemal Arslan , Osman Doğru, Ömer Karahan², Mehmet Ali Eryılmaz \\ ${ }^{1}$ Konya Eğitim ve Araştırma Hastanesi, Genel Cerrahi Kliniği, Konya, Türkiye \\ ${ }^{2}$ Uşak Üniversitesi Tıp Fakültesi, Genel Cerrahi Anabilim Dalı, Uşak, Türkiye
}

\section{ÖZET}

Giriş ve Amaç: Bu çalışmamızda; inguinal hernilerde minimal invaziv preperitonial (MiP) tek kat yama onarımı ile total ekstraperitonial (TEP) onarımının komplikasyonlar, rekürrens ve kronik ağrı yönünden karşılaştırmayı amaçladık.

Gereç ve Yöntem: Nisan 2011 ile Eylül 2012 tarihleri arasında elektif, primer, tek taraflı inguinal herni ameliyatı uygulanan toplam 240 hasta iki randomize gruba ayrıldı. İlk gruba MiP onarımı yapıldı ve ikinci gruba TEP onarımı yapıldı. Kronik ağrının değerlendirilmesinde Visual Analog Skala (VAS) ve Sheffield Skalası (SS) kullanıldı.

Bulgular: Hastaların \%95 (225 hasta)'i takipte kaldı ve analizlere dahil edildi. Demografik özellikler, ameliyat süresi veya intraoperatif, erken veya geç komplikasyonlar açısından gruplar arasında anlamlı bir fark saptanmadı. İşe dönüş için geçen süre TEP grubunda anlamlı olarak daha kısaydı $(p<0.001)$. MiP grubunda $1(\% 0.88)$ hastada ve TEP grubunda $1(\% 0.89)$ hastada nüks görüldü ( $p=0.993)$. Kronik ağrının değerlendirilmesi postoperatif 6,12 ve 24. aylarda VAS ve SS değerlerinde gruplar arasında anlamlı bir fark olmadığını ortaya koydu.

Sonuç: Sonuç olarak, inguinal herni için MiP onarımının, preperitoneal onarımın tüm avantajlarına sahip olduğu ve TEP onarımının dezavantajlarını ortadan kaldırdığı görülmüştür. MiP tekniği, TEP onarımı kadar güvenlidir ve açık bir müdahale olmasına rağmen, kronik ağrı açısından benzer niteliklere sahiptir.

Anahtar Kelimeler: Kronik ağrı, inguinal herni, preperitonial onarım, total ekstra peritonial onarım

Doi: $10.5578 /$ turkjsurg. 4128 